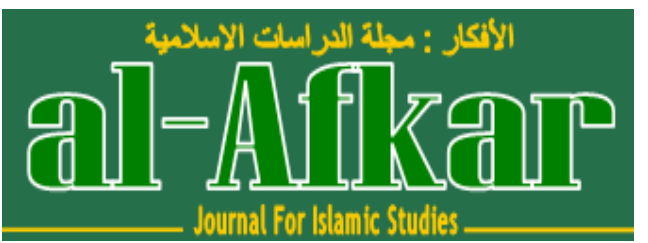

Vol. 2, No. 2, July 2019

P-ISSN : 2614-4883; E-ISSN : 2614-4905

https://al-afkar.com/index.php/Afkar_Journal/issue/view/4

DOI: https://doi.org/10.31943/afkar_journal.v4i1.63

\title{
KONSEP BIMBINGAN DAN KONSELING DALAM MENGATASI KENAKALAN SISWA (Studi Kasus di MTs Al-Gozali Jatibarang Kabupaten Indramayu)
}

\section{Ibnudin}

Fakultas Agama Islam Universitas Wiralodra

E-Mail: ibnufauzanhariri@gmail.com

\begin{tabular}{|c|c|c|}
\hline Received & Revised & Accepted \\
\hline 3 Juny 2019 & 20 Juny 2019 & 1 July 2019 \\
\hline
\end{tabular}

\section{THE CONCEPT OF GUIDANCE AND COUNSELING IN OVERCOMING} STUDENT DELINQUENCY

\author{
(The Case Study AT MTs AL-GOZALI Jatibarang in Indramayu District)
}

\begin{abstract}
Abstrak
Penelitin ini bertujuan untuk menelusuri: (1) peran bimbingan dan konseling dalam mengatasi kenakalan siswa dan (2) implikasi pelaksanaan bimbingan dan konseling dalam mengatasi kenakalan siswa. Dalam penelitian ini menggunakan pendekatan kualitatif jenis studi kasus. Data diperoleh dengan menggunakan metode wawancara mendalam, pengamatan partisipan, dan dokumentasi. Hasil penelitian menunjukan bahwa: (1) bimbingan dan konseling memiliki peranan yang sangat strategis dalam kegiatan pembelajaran yang dilakukan di sekolah, pelaksanaan bimbingan konseling bisa diintegrasikan dengan berbagai kegiatan lainya di lingkungan sekolah; (2) dampak dari kegiatan bimbingan konseling dapat menjadi wadah utama untuk menyalurkan minat dan bakat siswa, dengan demikian peran dan fungsi bimbingan konseling adalah sebagai proses pencegahan dan proses pengobatan terhadap berbagai permasalahan dalam pembelajaran
\end{abstract}

Kata kunci: bimbingan dan konseling, kenakalan siswa, dan peran guru. 
Ibnudin

Konsep Bimbingan dan Konseling dalam......

\begin{abstract}
This resear aims to explore: (1) the role of guidance and conselling to cure student delinquency and (2) the implication of implementation of guidance and conselling to cure student delinquency.this research was qualitative approach by case studies. The data were obtained by depth-interview, participant observation, and documentation. The results showed that: (1) guidance and counseling have a very strategic role in learning activities which carried out in schools, the implementation of counseling can be integrated with various other activities in the school environment; (2) the impact of counseling activities can be the main forum for channeling students' interests and talents, thus the role and function of counseling is as the prevention process and treatment of various problems in learning
\end{abstract}

Keywords: guidance and consseling, student delinquency, and role of teacher

\title{
Pendahuluan
}

Kenakalan Siswa pada usia remaja bukanlah hal baru.masalah ini sudah ada sejak berabad abad yang lampau. Kenakalan remaja pada setiap generasi berbeda karena pengaruh lingkungan kebudayaan dan sikap mental masyarakat pada masa itu.Masa remaja adalah suatu tahap kehidupan yang bersifat peralihan dan tidak mantap.Di samping itu, masa remaja adalah masa yang rawan oleh pengaruh negatif, seperti narkoba,kriminal,dan kejahatan seks.namun kita harus mengakui pula.bahwa masa remaja adalah masa yang amat baik untuk mengembangkan segala potensi positif yang mereka miliki seperti bakat, kemampuan, dan minat. Selain itu, sebaiknya mereka diberi bimbingan agama agar menjadi pedoman hidup baginya. ${ }^{1}$

Sekolah dan madrasah memiliki tanggung jawab yang besar membantu siswa agar berhasil dalam belajar.untuk itu sekolah Dan madrasah hendaknya memberikan bantuan kepada siswa untuk mengatasi masalah-masalah yang timbul dalam kegiatan belajar siswa dalam kondisi seperti ini, pelayanan bimbingan dan konseling sekolah dan madrasah sangat penting untuk dilaksanakan guna membantu siswa mengatasi berbagai masalah yang di hadapinya ${ }^{2}$. Manusia tidak sama satu dengan yang lainnya. Baik dalam sifat maupun kemampuannya.Ada manusia yang sanggup mengatasi persoalan tanpa bantuan pihak lain, tetapi tidak sedikit manusia yang tidak mampu mengatasi persoalan bila tidak dibantu orang lain. Khususnya bagi yang terakhir inilah bimbingan dan konseling sangat diperlukan.Manusia perlu mengenal dirinya sendiri dengan sebaik-baiknya. Dengan mengenal dirinya sendiri, mereka akan dapat bertindak dengan tepat sesuai dengan kemampuan yang ada pada dirinya. Walaupun demikian tidak semua manusia mampu mengenal segala kemampuan dirinya. Mereka ini memerlukan bantuan orang lain agar dapat mengenal diri sendiri, lengkap dengan segala kemampuan

\footnotetext{
${ }^{1}$ Sofyan S Willis, "Remaja Dan Masalahnya," 2017.

${ }^{2}$ A Tohirin and M Pd, "Bimbingan Dan Konseling Di Sekolah Dan Madrasah," Jakarta: Raja Grafindo Persada, 2007.
} 
Ibnudin

Konsep Bimbingan dan Konseling dalam......

yang dimilikinya dan bantuan tersebut dapat diberikan oleh bimbingan dan konseling pada kenyataannya.

Bimbingan dan konseling juga diperlukan, baik oleh masyarakat yang belum maju maupun masyarakat yang modern hal tersebut akan dibicarakan lebih lanjut dalam perkembangan bimbingan dan konseling ${ }^{3}$ lebih dalam masyarakat yang modern karena persoalan persoalan yang timbul dalam masyarakat modern sangatlah kompleks ${ }^{4}$. Makin maju suatu masyarakat maka akan makin kompleks persoalan yang dihadapi oleh anggota masyarakatnya.Kegiatan bimbingan dan konseling ini berbeda dengan kegiatan mengajar, karena itu sangatlah perlu adanya bimbingan dan konseling ini untuk tiap-tiap sekolah.

Perbedaannya yaitu kegiatan mengajar sudah dirumuskan terlebih dahulu dan target pencapaiannya sama untuk seluruh siswa, akan tetapi kegiatan bimbingan dan konseling target dan pencapaiannya lebih bersifat individual atau kelompok, pembicaraan dalam kegiatan mengajar lebih banyak diarahkan pada pemberian informasi, atau pembuktian dalam satu masalah, sedangkan dalam konseling lebih ditujukan untuk memecahkan masalah yang dihadapi klien, kemudian dalam kegiatan mengajar, para siswa belum tentu mempunyai masalah yang berkaitan dengan materi yang diajarkan, sedangkan dalam bimbingan dan konseling pada umumnya klien telah/sedang menghadapi masalah. Juga dalam melaksanakan bimbingan konseling, bagi konselor dituntut suatu keterampilan khusus dan berbeda dengan tuntutan bagi seorang guru /pengajar. ${ }^{5}$

Jika kita menelusuri perkembangan dari profesi konseling mencermati beberapa persoalan yang berharga, serta masalah-masalah profesional yang cenderung dapat mengacaukannya dan mengamati secara luas akan kondisi dimana konselor berusaha menegakkan identitas dan kekhassan profesionalnya,elemen esensial bagi dasar seperti diatas tersebut, terletak pada gagasan-gagasannya, tujuannya, serta cara pendekatannya yang terpadu di dalam bidang lingkungan perkembangan manusia atau ekologi perkembangan manusia begitu kita sadar akan munculnya permasalahan di dalam dunia yang sepertinya laju karena keracunan dirinya sendiri, kita menjadi semakin menyadari kenyataan berapa rapuhnya benang dimana bergantung bekal kehidupan dari lingkungan fisik kita. ${ }^{6}$ Beberapa ahli juga menyatakan bahwa bimbingan dan konseling semakin hari semakin dirasakan perlu keberadaanya disetiap sekolah. Hal ini didukung oleh beberapa faktor seperti :

1. Sekolah merupakan lingkungan hidup kedua sesudah rumah, dimana anak dalam waktu sekian jam (kurang lebih 6 jam) hidupnya berada disekolah.

\footnotetext{
${ }^{3}$ Walgito Bimo, "Bimbingan Dan Konseling (Studi Dan Karir)" (Yogyakarta: Andi Offset, 2010).

4 Ibnu Rusydi, "Paradigma Pendidikan Agama Integratif-Transformatif," Jurnal Pendidikan Islam, 1970, https://doi.org/10.14421/jpi.2011.11.105-120.

${ }^{5}$ Koestoer Parwisastro, Standar Kompetensi Guru Dan Sertifikasi Guru, ( Jakarta : PT Remaja, 1982), 5.

${ }^{6}$ Mungin Eddy Wibowo, "Konseling Kelompok Perkembangan" (Semarang: UNNES Press, 2005).
} 
Ibnudin

Konsep Bimbingan dan Konseling dalam......

2. Para siswa yang usianya relative masih muda sangat membutuhkan bimbingan baik dalam memahami keadaan dirinya, mengarahkan dirinya, maupun dalam mengatasi berbagai macam kesulitan.

Selain itu kehadiran konselor disekolah juga dapat meringankan tugas guru seperti mengatasi masalah-masalah yang ditemui guru dalam melaksanakan tugasnya, mengembangkan dan memperluas pandangan guru tentang masalah afektif yang mempunyai kaitan erat dengan profesinya sebagai guru dll. Oleh karena itu konselor dan guru/ pengajar merupakan suatu tim yang sangat penting dalam kegiatan pendidikan. Karena keduanya dapat saling menunjang terciptanya proses pembelajaran yang efektif. Itu sebabnya kegiatan bimbingan dan konseling sangat perlu dilakukan karena keduanya tidak dapat dipisahkan dengan kegiatan Sekolah. ${ }^{7}$

Di dalam buku Prof.Dr.Sofyan S Willis, M.Pd. ini menurut saya sangat bagus sekali dan banyak pengetahuan dan maanfaat yang sebelumnya saya ketahui banyak sekali pembahasan-pembahasan di dalam nya mengenai remaja dan sesuai dengan apa yang menjadi judul penelitian saya, buku remaja dan narkoba menguraikan segala aspek kehidupan sosial, psikologis dan kultural dari para remaja. Kemudian diungkapkan juga tentang kenakalan remaja, yang berdampak terhadap kecanduan narkoba, yang dapat menjurus ke perbuatan-perbuatan negatif.oleh karena nya masa remaja sangatlah penting untuk di perhatikan dan diberikan bimbingan terhadap keluarga dan guru atau sekitarnya, karena begitu luas dan pentingnya masalah remaja ${ }^{8}$.

Sangat banyak rumusan pengertian bimbingan dan konseling dapat ditemukan dalam berbagai literatur. Umumnya rumusan tentang bimbingan dan konseling yang ada mempunyai benang merah yang mempertemukan antara satu pengertian dengan pengertian yang lainnya.

Keberadaan bimbingan dan konseling (BK) di sekolah akan semakin dirasa perlu jika pelayanan BK tersebut mampu memberikan kontribusi yang berarti terhadap upaya memperkuat fungsi dan tujuan pendidikan sebagaimana dijelaskan dalam UU No 20 Tahun 2003 pasal 1 ayat 1 tentang sistem pendidikan Nasional. Pendidikan adalah usaha sadar dan terencana untuk mewujudkan suasana belajar dan proses pembelajaran agar peserta didik secara aktif mengembangakan potensi dirinya untuk memiliki spiritual, pengendalian diri, kepribadian, kecerdasan, akhlak mulia, serta ketrampilan yang diperlakukan dirinya,masyarakat. ${ }^{9}$

Dalam praktik, bimbingan dan konseling merupakan satu kesatuan aktifitas yang tidak terpisahkan. Keduanya merupakan bagian yang integral. ${ }^{10}$ Pengertian

\footnotetext{
${ }^{7}$ Tohirin, Bimbingan Dan Konseling di Sekolah Dan Madrasah,( Jakarta : RajaGrafindo, 2007 ), 54.

${ }^{8}$ Ibnu Rusydi, "FILSAFAT POLITIK ISLAM; Sebuah Pengantar," Risâlah, Jurnal Pendidikan Dan Studi Islam 2, no. 1 (2015): 110-23.

${ }^{9}$ Ali Miftakhu Rosyad, "The IMPLEMENTASI NILAI-NILAI MULTIKULTURALISME MELALUI PEMBELAJARAN PENDIDIKAN AGAMA ISLAM (THE IMPLEMENTATION OF MULTICULTURALISM VALUES THROUGH LEARNING OF ISLAMIC RELIGION EDUCATION)," Risâlah, Jurnal Pendidikan Dan Studi Islam 5, no. 1 (2019): 1-18.

${ }^{10}$ Tohirin and Pd, "Bimbingan Dan Konseling Di Sekolah Dan Madrasah."
} 
Ibnudin

Konsep Bimbingan dan Konseling dalam......

bimbingan sangat banyak dikemukakan pakar-pakar bimbingan dan konseling, terutama yang berasal dari Amerika Serikat, negara asal bimbingan dan konseling itu. Pada mulanya bimbingan dimaksudkan sebagai Usaha membantu para pemuda agar mendapatkan pekerjaan. Hal ini berguna untuk mengatasi kenakalan remaja, dengan asumsi bahwa memberikan pekerjaan diharapkan ketegangan emosional dan keliaran remaja dapat berkurang.Sekarang bimbingan tidak saja ditujukan untuk mendapatkan pekerjaan dan membantu individu mengatasi masalah-masalah yang dihadapi dalam pekerjaan. Akan tetapi mencangkup segala aspek kehidupan individu.

Adapun arti lain dari bimbingan yaitu bimbingan diberikan kepada semua orang yang membutuhkannya sifatnya bukan paksaan, akan tetapi atas dasar kerelaan dan kesadaran individu tersebut ia memahami bahwa kesulitannya itu memerlukan bantuan orang lain (pembimbing) agar si terbimbing (klien) dapat mengatasinya" dalam praktik, bimbingan dan konseling merupakan satu kesatuan aktifitas yang tidak terpisahkan. Keduanya merupakan bagian yang integral. ${ }^{12}$

Bimbingan dan konseling merupakan terjemahan dari "guidance" dan "counseling" dalam bahasa inggris. Secara harfiyah istilah "guidance' dari akar kata "guide" itu Mengarahkan dan memandu.

Banyak pengertian bimbingan yang dikemukakan oleh para ahli, diantaranya yaitu:

1. Bimbingan merupakan suatu proses yang berkesinambungan bukan kegiatan yang seketika atau kebetulan bimbingan merupakan serangkaian

2. tahapan kegiatan kegiatan yang sistematis dan berencana yang terarah kepada pencapaian tujuan. ${ }^{13}$

Bimbingan merupakan "helping" yang berarti bantuan makna bantuan dalam bimbingan menunjukan bahwa yang aktif dalam mengembangkan diri, mengatasii masalah, atau mengambil keputusan adalah individu atau peserta didik sendiri. Dalam proses bimbingan, pembimbing tidak memaksakan kehendaknya sendiri, tetapi berperan sebagai fasilator istilah bantuan dalam bimbingan dapat juga dimaknai sebagai upaya untuk menciptakan lingkungan, fisik, psikis, sosial, dan spiritual. Yang kondusif bagi perkembangan siswa, memberikan dorongan dan semangat, mengembangkan keberanian bertindak dan bertanggung jawab, mengembangkan kemampuan untuk memperbaiki dan mengubah prilakunya sendiri.

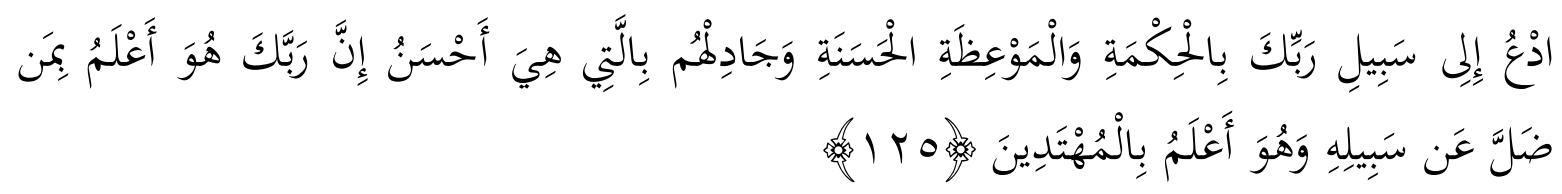

\footnotetext{
${ }^{11}$ Willis, "Remaja Dan Masalahnya."

${ }^{12}$ Tohirin and Pd, "Bimbingan Dan Konseling Di Sekolah Dan Madrasah."

${ }^{13}$ Syamsu Yusuf and A Juntika Nurihsan, "Landasan Bimbingan \& Koseling Bandung: PT," Remaja Rosdakarya, 2012.
} 
Ibnudin

Konsep Bimbingan dan Konseling dalam......

Serulah (manusia) kepada jalan Tuhan-mu dengan hikmah dan pelajaran yang baik dan bantahlah mereka dengan cara yang baik. Sesungguhnya Tuhanmu Dialah yang lebih mengetahui tentang siapa yang tersesat dari jalan-Nya dan Dialah yang lebih mengetahui orang-orang yang mendapat petunjuk. (QS. An-Nahl:125) ${ }^{14}$

Secara historis asal mula pengertian konseling adalah untuk memberi nasehat, seperti penasehat hukum, penasehat perkawinan, dan penasehat camping anak-anak pramuka. Kemudian nasehat itu berkembang ke bidang-bidang bisnis, manajemen, investasi, dan finansial.

Misalnya ada penasehat otomotif (outomotive counselor) pengetian konseling dalam kegiatan-kegiatan seperti tersebut di atas menekankan pada nasehat mendorong, memberi informasi, menginterpretasi hasil tes, dan analisis psikologis.

Kemudian mengemukakan arti konseling itu Suatu hubungan antara seseorang dengan orang lain, dimana seorang berusaha keras untuk membantu orang lain agar memahami masalah dan dapat memecahkan masalahnnya dalam rangka penyesuaian dirinya. ${ }^{15}$ dalam era global dan pembangunan maka konseling lebih menekankan pada pengembangan potensi individu yang terkandung dalam dirinya, termasuk dalam potensi itu adalah aspek intelektual afektif, sosial, emosional, dan religius. Sehingga individu akan berkembang dengan nuansa yang lebih bermakna, harmonis, sosial, dan bermanfaat maka definisi konseling yang antisipatif sesuai tantangan pembangunan.

Konseling adalah upaya bantuan yang diberikan seorang pembimbing yang terlatih dan berpengalaman, terhadap individu-individu yang membutuhkannya, agar individu tersebut berkembang potensinya secara optimal, mampu mengatasi masalahnya dan mampu menyesuaikan diri terhadap lingkungan yang selalu berubah.

\section{Metode Penelitian}

\section{Jenis Penelitian}

Penelitian ini menggunakan kualitatif dengan jenis studi kasus. Studi kasus adalah salah satu jenis pendekatan kualitatif yang penelitianya mengeksplorasi kehidupan nyata, sistem terbatas kontemporer (kasus) atau beragam sistem terbats (berbagai kasus), melalui pengumpulan data yang detail dan mendalam yang melibatkan beragam sumber informasi dan melaporkan deskripsi kasus dan tema kasus terhadap berbagai berbagai peristiwa-peristiwa dan aktivitas yang terjadi di MTs Al-Gozali Kecamatan Jatibarang Kabupaten Indramayu yang meliputi ${ }^{16}$. Pendekatan dalam penelitian ini adalah naturalistik artinya peneliti tidak berusaha memanipulasi latar penelitian, tetapi melakukan studi terhadap suatu

\footnotetext{
${ }^{14}$ Departemen Agama RI, Al-Qur'an dan terjemahannya (Jakarta: Lintas Media, 2006)

${ }^{15}$ Sofyan S Willis, Konseling Individual Teori dan Praktik, ( Bandung : Alfabeta, 2009 ), 17.

${ }^{16}$ John W Creswell, "Penelitian Kualitatif \& Desain Riset Memilih Diantara Lima Pendekatan," Yogyakarta: Pustaka Pelajar, 2015.
} 
Ibnudin

Konsep Bimbingan dan Konseling dalam......

fenomena/peristiwa. Fokus penelitian dapat berupa orang, kelompok, program, pola hubungan, ataupun interaksi semuanya itu dilihat dalam konteks alamiah. Dengan demikian, peneliti melalui pengalaman peneliti berusaha mengkonstruksi pandangan tentang dunia sekitar ${ }^{17}$.

\section{Setting Penelitian}

Penelitian ini dilaksanakan di MTs Al-Gozali Kecamatan Jatibarang, kabupaten Indramayu, Provinsi Jawa Barat (0234) 275216. Waktu penelitian dimulai sejak April sampai dengan Mei 2019.

\section{Unit Analisis}

Unit analisis dalam penelitian ini adalah (1) konsep pelaksanaan bimbingan dan konseling; dan (2) implikasi bimbingan dan konseling dalam mengatasi kenakalan siswa.

\section{Subjek Penelitian}

Subjek penelitian ditentukan dengan berdasarkan pertimbangan tertentu (purposive sampling). Pertimbangan tersebut adalah kesesuaian antara apa yang diteliti dengan informan. Subyek penelitian yaitu: (a) kepala sekolah, (b) wakil kepala sekolah bidang kesiswaan, (c) guru BK, (e) guru PKN, dan (f) siswa yang dilakukan di MTs Al-Gozali Kecamatan Jatibarang Kabupaten Indramayu. Teknik purposive sampling dilakukan dengan cara memilih sejumlah responden yang disesuaikan dengan tujuan penelitian. Dalam studi fenomenologi individu yang akan dijadikan informan adalah mereka yang dapat memberikan penjelasan dengan baik.

\section{Sumber Data}

Sumber data dalam penelitian kualitatif dapat digolongkan menjadi dua yaitu sumber data primer dan sumber data sekunder. Sumber data primer dalam penelitian ini adalah data yang diperoleh langsung dari subyek penelitian tentang konsep bimbingan dan konseling dalam mengatasi kenakalan siswa, studi kasus di MTs Al-Gozali Kecamatan Jatibarang Kabupaten Indramayu. Sedangkan sumber data sekunder adalah sumber data tambahan yang berupa dokumen dan bahan kepustakaan yang dianggap relevan dengan penelitian.

\section{Teknik dan Instrumen Pengumpulan Data}

Dalam konteks penelitian kualitatif, pengumpulan data sering dilakukan dengan melihat kondisi alamiah (natural setting), sumber data primer, dan teknik pengumpulan data lebih banyak pada observasi berperan serta (particifan observation), wawancara mendalam (in depth interview) dan dokumentasi ${ }^{18}$. Oleh karena itu, dalam penelitian ini instrumen pengumpul data yang utama adalah (key instrument) yaitu peneliti sendiri. Adapun teknik pengumpulan data yang digunakan dalam penelitian ini adalah:

\footnotetext{
${ }^{17}$ M Djunaidi Ghony and Fauzan Almanshur, “Metodologi Penelitian Kualitatif," Jogjakarta: Ar-Ruzz Media, 2012.

${ }^{18}$ Sugiyono, Metode Penelitian Pendidikan:(Pendekatan Kuantitatif, Kualitatif Dan R \& D) (Alfabeta, 2008).
} 
Ibnudin

Konsep Bimbingan dan Konseling dalam......

1. Observasi, dalam hal ini, peneliti terjun langsung ke lokasi penelitian dan ikut berpartisipasi sebagai asisten pembina ekstrakurikuler dalam kegiatan yang terjadi di lingkungan sekolah sambil melakukan pengamatan. Akan tetapi pada saat ada kegiatan yang dilakukan oleh siswa peneliti memberhentikan pengamatan karena berbagai pertimbangan yang menimbulkan dampak seperti mengganggu kegiatan tersebut, sehingga peneliti mengamati dari kejauhan. Observasi dilaksanakan di MTs Al-Gozali Kecamatan Jatibarang Kabupaten Indramayu, adapun subjek yang diobservasi antara lain; (a) kegiatan di dalam kelas, seperti proses belajar mengajar, diskusi kelompok. (b) kegiatan bimbingan dan konseling di lingkungan sekolah.

2. Wawancara, dalam penelitian ini bentuk wawancara terhadap informan dengan menggunakan pedoman wawancara yaitu membuat catatan tentang pokok-pokok pertanyaan yang sesuai dengan tujuan penelitian. Berangkat dari pendapat tersebut, peneliti melakukan wawancara dengan dua cara; yaitu wawancara terstruktur, dengan wawancara tidak terstruktur yang ditujukan kepala sekolah, wakil kepala sekolah bidang kesiswaan, guru BK, guru PKN, guru PAI, dan siswa mengenai proses konsep bimbingan dan konseling dalam mengatasi kenakalan siswa, studikasus di MTs Al-Gozali Kecamatan Jatibarang Kabupaten Indramayu. Berikut akan dijelaskan tabel mengenai kisi-kisi wawancara yang digunakan dalam penelitian ini:

3. Dokumentasi dalam penelitian ini adalah suatu proses pengambilan beberapa dokumen yang dijadikan sebagai bukti rasional dan empirik yang terkait dengan tujuan penelitian. Pada tahap ini, peneliti meminta profil sekolah MTs Al-Gozali Kecamatan Jatibarangsebagai langkah awal untuk melihat kondisi sekolah tersebut, dan itu peneliti jadikan dokumen sebagai data pendukung. Selanjutnya peneliti mengambil data-data penting lainnya, seperti latar belakang siswa dalam hal ini peneliti meminta data dari TU (tata usaha) dan yang terpenting adalah mencari data mengenai latar belakang guru dan kepala sekolah serta dekumentasi kurikulum yang tertulis. Data tersebut bisa dijadikan data analisis dokumentasi karena kaitannya dengan pelaksanaan bimbingan dan konseling dalam mengatasi kenakanal siswa. Berikut ini akan dijelaskan gambaran tentang teknik pengumpulan data yang dilakukan secara interaktif sebagai berikut.

Menurut Bogdan \& Bike analisis data adalah upaya yang dilakukan dengan bekerja dengan data, mengorganisasi data, memilah-milahnya menjadi satuan data yang dapat dikelola, mensintesiskan data, mencari dan menemukan pola, menemukan apa yan penting dan apa yang dipelajari, dan memutuskan apa yang dapat diceritakan kepada orang lain.

Dalam penelitian ini digunakan teknik analisis model interaktif yaitu dengan menggunakan langkah-langkah sebagai berikut.

1. Pengumpulan data 
Ibnudin

Konsep Bimbingan dan Konseling dalam......

Data dikumpulkan dengan tujuan untuk memperoleh atau mendapat informasi di lapangan sesuai dengan kebutuhan peneliti dan rumusan masalah sehingga memungkinkan data tersebut harus akurat.

2. Reduksi data

Data yang diperoleh di lapangan semakin bertambah banyak, sehingga perlu dilakukan reduksi, dirangkung, dipilih, diberi kode dan diambil yang penting dari tema dan polanya. Melalui proses reduksi data laporan mentah di lapangan menjadi lebih sistemati sehingga mudah dikendalikan.

3. Penyajian data

Setelah data direduksi maka, langkah berikutnya adalah menyajikan data. Dalam penelitian ini, penyajian data dilakukan dalam bentuk uraian teks yang bersifat deskriptif yang mengungkapkan tentang aktualisasi pendidikan karakter berbasis kultur sekolah dalam pembelajaran PAI pada empat dimensi yaitu perencanaan pendidikan karakter berbasis kultur sekolah, pelaksanaan pendidikan karakter berbasis kultur sekolah, penilaian pendidikan karakter berbasis kultur sekolah, dan peran kultur sekolah dalam pendidikan karakter. Selain itu, menyajikan data yang berhubungan dengan dukungan komite sekolah, orang tua, dan masyarakat melalui kultur sekolah serta aktualisasi pendidikan karakter malalui kultur sekolah meliputi kegiatan rutinitas, kegiatan spontanitas, keteladanan, dan pengkondisian lingkungan.

4. Pengambilan Simpulan

Pengambilan simpulan dilakukan untuk menyederhanakan data dan informasi yang diperoleh guna mencapai pola, tema, hubungan, persamaan, dan hal-hal lain yang sering timbul. Pengambilan simpulan ini diklarifikasi dan diverifikasi selama penelitian berlangsung.

\section{Hasil Penelitian dan Pembahasan}

\section{Peran Bimbingan dan Konseling dalam mengatasi kenakalan siswa di MTs Al- Gazali Jatibarang}

Bimbingan dan konseling adalah pelayanan bantuan untuk siswa, baik secara perorangan maupun kelompok agar mandiri dan bisa berkembang secara optimal, dalam bimbingan pribadi, sosial, belajar maupun karier melalui berbagai jenis layanan dan kegiatan pendukung berdasarkan norma-norma yang berlaku.

Dari hasil penelitian ini, Pelaksanaan bimbingan dan konseling di MTs AlGazali Jatibarang didasarkan pada tingkatan perkembangan dan kebutuhan peserta didik, hal ini dilakukan agar kegiatan bimbingan dan konseling yang diberikan dapat sesuai dengan permasalahan yang dihadapi peserta didik. Pelaksanaan bimbingan dan konseling MTs Al-Gazali Jatibarang dilaksanakan secara terprogram, terarah, teratur, dan berkelanjutan. 
Ibnudin

Konsep Bimbingan dan Konseling dalam......

Pelaksanaan bimbingan dan konseling di MTs Al-Gazali Jatibarang meliputi program bimbingan dan konseling yaitu bimbingan kelompok, bimbingan individu, dan bimbingan klasikal. Keberhasilan pelaksanaan bimbingan dan konseling

tidak terlepas dari peran aktif guru pembimbing. Oleh karena itu, guru bimbingan dan konseling dituntut untuk bisa berbuat dan melaksanakan program-program kerja, satuan kegiatan bimbingan dan konseling, dan kegiatan pendukung manajemen bimbingan dan konseling

Dalam pelaksanaan bimbingan dan konseling di MTs Al-Gazali Jatibarang, guru bimbingan dan konseling harus senantiasa menjalin kerjasama dengan semua pihak madrasah maupun orang tua peserta didik dan instansi lain yang berhubungan dengan pelaksanaan bimbingan dan konseling. Hal ini dimaksudkan agar guru bimbingan dan konseling mengalami kemudahan dalam melaksanakan tugas bimbingan dan konseling. Pelaksanaan bimbingan dan konseling di MTs AlGazali Jatibarang.

Sebenarnya bukan hanya untuk peserta didik yang bermasalah saja, lebih dari itu guru pembimbing harus selalu memberikan informasi kepada peserta didik tentang berbagai hal dalam upaya mengembangkan kemampuan atau potensi peserta didik.

Sebagai pelaksana bimbingan dan konseling, guru pembimbing harus mengetahui dan memahami tentang metode dan teknik dalam bimbingan dan konseling. Tanpa pengetahuan dan pemahaman mengenai berbagi metode dan teknik, guru pembimbing akan banyak mengalami kesulitan dalam pelaksanaan bimbingan dan konseling ${ }^{19}$.

Selain itu, metode dan teknik yang digunakan harus disesuaikan dengan kebutuhan dan permasalahan peserta didik di MTs Al-Gazali Jatibarang Seperti yang peneliti paparkan tadi hendaknya dari masing-masing kegiatan yang akan dijalankan ada penanggung jawab dalam pelaksanaannya, sehingga dapat diketahui hasil dari pelaksanaannya dan menjadi bahan rujukan untuk kegiatan selanjutnya, dan adanya pelaksanaan bimbingan dan konseling dapat membantu peserta didik dalam mengatasi kenakalan siswa dan agar dapat belajar dengan efektif dan efisien, diperlukan pengawasan dari kepala sekolah, karena pada pelaksanaannya monitoring sangat penting untuk mengetahui sejauh mana pelaksanaan kegiatan yang dijalankan.

Ada beberapa tindakan yang dapat dilakukan untuk mengatasi kenakalan siswa (student delinqueny) di MTs Al-Gazali Jatibarang, yaitu:

a) Tindakan Preventife

Pada dasarnya makna preventif ini sendiri yang berarti mencegah. Tindakan preventif ini merupakan suatu tindakan yang berfungsi untuk

\footnotetext{
${ }^{19} \mathrm{U}$ Abdullah Mumin, "PENDIDIKAN TOLERANSI PERSPEKTIF PENDIDIKAN AGAMA ISLAM (TELAAH MUATAN PENDEKATAN PEMBELAJARAN DI SEKOLAH)," Al-Afkar, Journal For Islamic Studies 2, no. 1 (2018): 15-26.
} 
Ibnudin

Konsep Bimbingan dan Konseling dalam......

mencegah timbulnya kenakalan remaja. Terkait dalam upaya mengatasi kenakalan remaja tindakan preventif ini dilakukan secara sistematis, terencana dan terarah, untuk menjaga agar kenakalan itu tidak timbul. Untuk mecegah kenakalan siswa di MTs Al-Gazali Jatibarang.

tindakan yang dilakukan guru Bimbingan dan Konseling adalah dengan mengadakan bimbingan secara klasikal didalam kelas selama dua jam pelajaran perminggu. Bimbingan yang diberikan berupa bimbingan karir, bimbingan sosial, dan bimbingan belajar ${ }^{20}$. Selain itu tindakan lain yang dilakukan adalah dengan memberikan nasehat dan wawasan-wawasan yang bertujuan untuk mendidik siswa untuk memiliki kepribadian yang lebih baik. Menurut peneliti tindakan preventif yang dilakukan oleh guru Bimbingan dan Konseling di MTs Al-Gazali Jatibarang sudah cukup baik karena guru Bimbingan dan Konseling sudah melaksanakan tugas sesuai dengan program bimbingan konseling yang ada di MTs Al-Gazali Jatibarang.

Selain itu guru Bimbingan dan Konseling sudah bekerja sama dengan kepala sekolah, wali kelas, guru-guru serta seluruh pihak sekolah dalam upaya mendidik siswa untuk menjadi lebih baik dan berakhlakul karimah.

b) Tindakan Preserfatif

Tindakan preserfatif ini merupakan usaha guru Bimbingan dan Konseling untuk membina siswa yang bermasalah agar tidak melakukan kenakalan dikemudian hari. Upaya yang dilakukan oleh guru pembimbing adalah dengan mengarahkan siswa untuk mengikuti kegiatan ekstrakurikuler, dengan mengarahkan siswa untuk mengikuti kegiatan ektrakurikuler diharapkan siswa dapat lebih menggunakan waktu luangnya untuk melakukan kegiatan yang lebih positive, kegiatan yang diarahkan guru Bimbingan Konseling diantaranya adalah siswa diwajibkan untuk mengikuti kegiatan kerohaniahan seperti istighosah dan tahlil yang diadakan rutin satu minggu sekali. Selain kegiatan tersebut siswa juga diarahkan untuk mengikuti kegiatan ekstrakurikuler yang lain seperti PMR, pramuka, silat, marawis dan marching band.

Menurut peneliti, tindakan yang dilakukan guru Bimbingan dan Konseling di MTs Al-Gazali Jatibarang sudah cukup baik, dengan mengarahkan siswa untuk mengikuti kegiatan ekstrakurikuler siswa menjadi lebih bisa menggunakan waktu luang mereka untuk kegiatan yang lebih positive dan tidak melakukan pelanggaran-pelanggaran yang ada di sekolah MTs Al-Gazali Jatibarang.

c) Tindakan kuratif Bimbingan dan Konseling dalam mengatasi kenakalan iswa

\footnotetext{
${ }^{20}$ Ali Miftakhu Rosyad, "Al-Afkar, Journal for Islamic Studies URGENSI INOVASI PEMBELAJARAN DALAM PENDIDIKAN AGAMA ISLAM Al-Afkar, Journal for Islamic Studies THE URGENCY OF LEARNING INNOVATION ON ISLAMIC RELIGIOUS STUDY" 3, no. 1 (2019), https://doi.org/10.5281/zenodo.2546882.
} 
Tindakan kuratif merupakan suatu tindakan yang dilakukan oleh guru Bimbingan dan Konseling dalam mengembalikan kondisi siswa yang sudah melakukan kenakalan atau pelanggaran agar normal kembali. Upaya lain yang dilakukan adalah dengan membantu menyelesaikan masalah yang dihadapi oleh siswa dan memberikan pengarahan yang intinya mendidik siswa untuk menambah keimanan, ketaqwaan dan kedisiplinan.

Menurut peneliti, tindakan kuratif yang dilakukan oleh guru Bimbingan dan Konseling cukup baik. Dengan memberi pengarahan dan penjelasan diharapkan cara berfikir serta wawasan siswa dapat lebih berkembang. Selain itu dengan adanya pemantauan terhadap siswa, guru dapat melihat sejauh mana keberhasilan dalam mengatasi kenakalan siswa

Tindakan kuratif merupakan tindakan yang dilakukan oleh guru Bimbingan Konseling dalam rangka menyembuhkan atau mengembalikan kondisi siswa yang pernah melakukan pelanggaran atau kenakalan dengan harapan siswa tersebut tidak akan mengulangi perbuatanya lagi. Fungsi bimbingan dan konseling yang bersifat kuratif ini berkaitan erat dengan upaya pemberian bantuan kepada siswa yang telah mengalami masalah, baik menyangkut aspek pribadi, sosial, belajar, maupun karir.

Adapun upaya yang dilakukan adalah dengan memberi pengarahan dan wawasan kepada siswa terutama untuk meningkatkan keimanan, ketaqwaan, sehingga yang dilakukan oleh guru bimbingan dan konseling dalam ham ini adalah komunikasi dari hati ke hati dengan tujuan memperbaiki mental siswa. Selain memberi pengarahan dan wawasan upaya lain yang dilakukan adalah dengan memantau terus perkembangan siswa yang sudah menjadi catatan pihak BK

Salah satu cara untuk menanggulangi dan mencegah terjadinya kenakalan adalah dengan diberlakukannya sanksi terhadap siswa yang melakukan pelanggaran. Sehingga diharapkan tidak terjadi pelanggaran dan menimbulkan efek jera terhadap siswa. Bentuk-bentuk sanksi yang diberlakukan tidak mengarah pada hal yang negatif, tetapi mengarah pada tindakan positif dari efek sanksi tersebut.

Berdasarkan wawancara dengan Ibu Heni Hidayatun N., S. Sos I., M. Si selaku guru Bimbingan Konseling di MTs Al-Gazali Jatibarang

Sanksi tersebut diberlakukan jika memang sudah terbukti secara jelas tindakan kenakalan yang dilakukan siswa. Ketika ada siswa yang melakukan kenakalan, maka pihak konselor akan melakukan langkah-langkah bimbingan dan konseling dan diberi peringatan. Jika memang siswa tersebut masih melakukan kenakalan lagi akan diberi hukuman ringan sesuai dengan tingkat kenakalan yang mereka lakukan. Hukuman selanjutnya jika siswa melaukan kenakalan lagi adalah dengan membuat surat pernyataan untuk tidak melakukanya lagi. Jika siswa masih melakukan kesalahan lagi maka guru bimbingan dan konseling akan memanggil orang tua untuk datang kesekolah 
Ibnudin

Konsep Bimbingan dan Konseling dalam......

dan diberi peringatan tentang tingkah laku anaknya disekolah. Selanjutnya diberi hukuman tidak boleh mengikuti pelajaran. Dan langkah pemberian hukuman terakhir adalah dikeluarkan dari sekolahan. (Hasil wawancara dengan Ibu Heni Hidayatun N., Sos.I. M.Si, tanggal 10 Mei 2016

Layanan bimbingan dan konseling pada umumnya merupakan bagian yang sangat penting dari keseluruhan proses pendidikan disekolah. Oleh karena itu, pelaksanaan layanan ini menjadi tanggung jawab bersama antara seluruh personil sekolahan, yaitu: kepala sekolah, guru BK, guru, wali kelas, dan petugas lainya. Sema personil sekolah terkait dalam pelaksanaan program bimbingan, karena bimbingan merupakan salah satu unsur pendidikan dari sistem pendidikan.

Kegiatan bimbingan mencakup berbagai aspek yang satu sama lain saling berkaitan, sehingga hal itu tidak mungkin jika pelayanan itu hanya dilakukan dan menjadi tanggung jawab konselor saja. Karena masalah-masalah peserta didik saat ini cukup kompleks, sehingga membutuhkan penanganan serta penanggulangan yang cukup serius.

\section{Implikasi Bimbingan dan Konseling dalam mengatasi kenakalan siswa}

Peran bimbingan konseling islam dalam mengatasi kenakalan siswa tidak lepas dari empat fungsi bimbingan koseling itu sendiri, yaitu: pencegahan (prefentif), pemahaman (kuratif), perbaikan (repserfatif), pemeliharaan dan pengembangan (developmental). Akan tetapi, pelayanan Bimbingan dan Konseling di MTs Al-Gazali Jatibarang

ini pada umumnya mengedepankan tiga fungsi, yaitu: preventif, preserfatif, kuratif. (Hasil wawancara dengan Ibu Heni Hidayatun N., Sos.I. M.Si, tanggal 10 Mei 2019). siswa

a) Fungsi preventif bimbingan dan konseling dalam mengatasi kenakalan

Dalam hal ini Bimbingan dan Konseling berfungsi memberikan pelayanan yang berguna untuk memahami keadaan siswa dan lingkungannya, serta memberikan pemahaman siswa terhadap informasi yang mereka perlukan.

Adapun dalam usaha pecegahan (preventif) secara umum dibagi menjadi tiga, antara lain: (1) usaha mengenal dan memahami ciri khas dan ciri umum kenakalan siswa, (2) mengetahui kesulitan-kesulitan yang secara umum dialami siswa, karena setiap siswa tidak selalu sempurna dan salah satu penyebab kenakalannya adalah kekurangan atau kelemahan yang tidak diterima oleh siswa tersebut sebagai individu. Dalam tindakan ini berusaha untuk mengetahui kesulitan serta kelemahan yang menimbulkan kenakalan yang dilakukan pada siswa tersebut, (3) usaha pembinaan siswa, usaha pembinaan pada siswa ini bertujuan untuk memperkuat sikap mental siswa agar mampu menyelesaikan masalah yang dihadapinya. Upaya preventif yang dapat dilakukan melalui program BK disekolah diantaranya adalah: pemberian informasi, bimbingan kelompok, dan layanan mediasi. 
Ibnudin

Konsep Bimbingan dan Konseling dalam......

b) Tindakan Preserfative Bimbingan dan Konseling dalam mengatasi kenakalan siswa

Tindakan Preserfative yakni membantu individu menjaga agar situasi dan kondisi yang semula tidak baik (mengundang masalah) menjadi baik (terpecahkan) dan kebaikan itu bertahan lama ${ }^{21}$. Upaya yang dilakukan oleh guru Bimbingan dan Konseling dalam tindakan preservative ini adalah dengan meningkatkan kegiatan ekstrakurikuler yang bertujuan untuk memberikan kegiatan kepada siswa sehingga siswa dapat menggunakan waktu yang ada untuk melakukan kegiatan yang lebih positive.

c) Tindakan Kuratif Bimbingan dan Konseling dalam mengatasi kenakalam siswa

Tindakan kuratif merupakan tindakan yang dilakukan oleh guru Bimbingan Konseling dalam rangka menyembuhkan atau mengembalikan kondisi siswa yang pernah melakukan pelanggaran atau kenakalan dengan harapan siswa tersebut tidak akan mengulangi perbuatanya lagi. Fungsi bimbingan dan konseling yang bersifat kuratif ini berkaitan erat dengan upaya pemberian bantuan kepada siswa yang telah mengalami masalah, baik menyangkut aspek pribadi ${ }^{22}$, sosial, belajar, maupun karir.

Adapun upaya yang dilakukan adalah dengan memberi pengarahan dan wawasan kepada siswa terutama untuk meningkatkan keimanan, ketaqwaan, sehingga yang dilakukan oleh guru bimbingan dan konseling dalam ham ini adalah komunikasi dari hati ke hati dengan tujuan memperbaiki mental siswa. Selain memberi pengarahan dan wawasan upaya lain yang dilakukan adalah dengan memantau terus perkembangan siswa yang sudah menjadi catatan pihak BK.

\section{Simpulan}

Pelaksanaan Bimbingan dan Konseling dalam Mengatasi kenakalan siswa di MTs Al-Gazali Jatibarang Pelaksanaan bimbingan dan konseling di MTs Al-Gazali Jatibarang meliputi program bimbingan dan konseling yaitu bimbingan kelompok, bimbingan individu, dan bimbingan klasikal. Kurikulum 2013 mengharuskan madrasah untuk mengalokasikan 2 (dua) jam pelajaran per minggu bagi pelajaran pengembangan diri. Hal ini berarti di setiap madrasah paling tidak harus mengalokasikan 2 jam pelajaran bagi guru bimbingan dan konseling untuk Mengadakan bimbingan secara klasikal. Pada tahun ajaran 2018/2019 belum mengalokasikan 2 (dua) jam pelajaran perminggu, dan pertemuan secara klasikal di dalam kelas selama dua jam perminggu belum diadakan, dan baru mulai diadakannya pada tahun ajaran 2019/2020 - sekarang. Dalam praktiknya MTs AlGazali Jatibarang

\footnotetext{
${ }^{21}$ Amin Ridwan, "Peran Guru Agama Dalam Bimbingan Konseling Siswa Sekolah Dasar," Risâlah, Jurnal Pendidikan Dan Studi Islam 4, no. 1 (2017): 1-13.

${ }^{22}$ Evi Aeni Rufaedah, "KAJIAN NILAI-NILAI BIMBINGAN DAN KONSELING ISLAMI,(Telaah Berdasarkan AlQur'an Dan Al-Hadist)," Risâlah, Jurnal Pendidikan Dan Studi Islam 2, no. 1 (2015): 124-32.
} 
Ibnudin

Konsep Bimbingan dan Konseling dalam......

\section{DAFTAR PUSTAKA}

Bimo, Walgito. “Bimbingan Dan Konseling (Studi Dan Karir).” Yogyakarta: Andi Offset, 2010.

Creswell, John W. "Penelitian Kualitatif \& Desain Riset Memilih Diantara Lima Pendekatan.” Yogyakarta: Pustaka Pelajar, 2015.

Ghony, M Djunaidi, and Fauzan Almanshur. "Metodologi Penelitian Kualitatif." Jogjakarta: Ar-Ruzz Media, 2012.

Mumin, U Abdullah. "PENDIDIKAN TOLERANSI PERSPEKTIF PENDIDIKAN AGAMA ISLAM (TELAAH MUATAN PENDEKATAN PEMBELAJARAN DI SEKOLAH).” Al-Afkar, Journal For Islamic Studies 2, no. 1 (2018): 15-26.

Ridwan, Amin. "Peran Guru Agama Dalam Bimbingan Konseling Siswa Sekolah Dasar." Risâlah, Jurnal Pendidikan Dan Studi Islam 4, no. 1 (2017): 1-13.

Rosyad, Ali Miftakhu. "Al-Afkar, Journal for Islamic Studies URGENSI INOVASI PEMBELAJARAN DALAM PENDIDIKAN AGAMA ISLAM Al-Afkar, Journal for Islamic Studies THE URGENCY OF LEARNING INNOVATION ON ISLAMIC RELIGIOUS STUDY” 3, no. 1 (2019). https://doi.org/10.5281/zenodo.2546882.

- - - "The IMPLEMENTASI NILAI-NILAI MULTIKULTURALISME MELALUI PEMBELAJARAN PENDIDIKAN AGAMA ISLAM (THE IMPLEMENTATION OF MULTICULTURALISM VALUES THROUGH LEARNING OF ISLAMIC RELIGION EDUCATION).” Risâlah, Jurnal Pendidikan Dan Studi Islam 5, no. 1 (2019): 1-18.

Rufaedah, Evi Aeni. "KAJIAN NILAI-NILAI BIMBINGAN DAN KONSELING ISLAMI,(Telaah Berdasarkan Al-Qur'an Dan Al-Hadist).” Risâlah, Jurnal Pendidikan Dan Studi Islam 2, no. 1 (2015): 124-32.

Rusydi, Ibnu. "FILSAFAT POLITIK ISLAM; Sebuah Pengantar." Risâlah, Jurnal Pendidikan Dan Studi Islam 2, no. 1 (2015): 110-23.

___ . "Paradigma Pendidikan Agama Integratif-Transformatif." Jurnal Pendidikan Islam, 1970. https://doi.org/10.14421/jpi.2011.11.105-120.

Sugiyono. Metode Penelitian Pendidikan:(Pendekatan Kuantitatif, Kualitatif Dan $R$ E D). Alfabeta, 2008.

Tohirin, A, and M Pd. "Bimbingan Dan Konseling Di Sekolah Dan Madrasah." Jakarta: Raja Grafindo Persada, 2007.

Wibowo, Mungin Eddy. "Konseling Kelompok Perkembangan.” Semarang: UNNES Press, 2005.

Willis, Sofyan S. “Remaja Dan Masalahnya,” 2017.

Yusuf, Syamsu, and A Juntika Nurihsan. "Landasan Bimbingan \& Koseling Bandung: PT.” Remaja Rosdakarya, 2012. 
Ibnudin

Konsep Bimbingan dan Konseling dalam......

Farid Muhammad Daryanto, Bimbingan Dan Konseling Panduan Guru BK Dan Guru

Umum, Yogyakarta : Gava Media.2015

Glading T Samuel, 2012, Konseling Profesi yang Menyeluruh, Jakarta : Permata Puri

Gunarsa, Singgih, 1992, Konseling dan Psikoterapi, Jakarta : PT BPK Gunung Mungin Eddy Wibowo, 2005, Konseling Kelompok Perkembangan, UPT UNNES : Sudarmo. 